\title{
Recurrent Paranasal Sinus Squamous Cell Carcinoma
}

National Cancer Institute

\section{Source}

National Cancer Institute. Recurrent Paranasal Sinus Squamous Cell Carcinoma. NCI

Thesaurus. Code C148387.

The reemergence of paranasal sinus squamous cell carcinoma after a period of remission. 